Бибикова Л. В. Политическая полиция конца XIX - начала XX вв. и «революция»: игра понятием или реальная угроза? // Философия. Журнал Высшей школы экономики. 2018. - T. II, № 2. - C. 70-98.

\title{
Лювовь БивиковА*
}

\section{ПОЛИТИЧЕСКАЯ ПОЛИЦИЯ}

\section{КОНЦА ХІХ - НАЧАЛА ХХ ВВ. И «РЕВОЛЮЦИЯ»: ИГРА ПОНЯТИЕМ ИЛИ РЕАЛЬНАЯ УГРОЗА?**}

Аннотация: В статье рассматривается трактовка понятия «революция» различными структурами политической полиции Российской империи конца XIX - начала XX Bв. ( $\mathrm{A} e-$ партамент полиции, охранные отделения, губернские жандармские управления) - той совокупности государственных учреждений, которые должны были бороться с революцией. В рамках разработанной $\mathrm{P}$. Козеллеком истории понятий обращается внимание, что революция в отличие от понятий «смуты», «бунта», «восстания», «гражданской войны» - это нацеленность на изменение государственного строя, на принципиальные изменения в политической системе страны. Теоретической рамкой для экспликации этого подхода к делопроизводственным материалам политического сыска выступает концепция «уликовой парадигмы», предложенная К. Гинзбургом для описания процесса становления государственного контроля над обществом в европейских странах периода становящегося модерна. По мнению чинов политической полиции Российской империи, «революционерами» считались те, кто готовил свержение существующего строя в подполье. При этом жандармы к революционным легальным общественно-политическим силам относили всех, кто в местном обществе не позиционировал себя как «охранителей». Аепартамент полиции же расценивал в качестве «революционной угрозы», кроме собственно революционеров-подпольщиков, группы «радикалов», «оппозиционеров» и «радикальных либералов», но исключал из «агентов революции» «либералов» в целом. Внутри системы политической полиции сложилось два образа «революции», которые в общем соответствуют двум понятиям «революция», описанным Р. Козеллеком. Первый, хронологически более ранний: революцияэто сугубо политическое явление, связанное с изменением основ государственного строя (что, собственно, и произошло в 1905 году). Анализ делопроизводственной переписки политического сыска Российской империи рубежа XIX - XX вв. показывает, что руководству политической полиции (то есть чинам Аепартамента полиции) к началу хх в. был ближе именно образ революции не «политической», но «социальной». В этом смысле события революционного 1905 года имели для них первостепенное значение не столько с точки зрения изменения государственного строя (как было для жандармов), сколько как неизбежное отражение трансформационных процессов, имевших место в российском обществе.

Ключевые слова: политическая полиция, понятие «революция», Аепартамент полиции, жандармерия, история идей, радикализм, правящие элиты Российской империи.

DOI: $10.17323 / 2587-8719-2018-$ II-2-70-98.

*Бибикова Любовь Владимировна, к. ист. н., старший преподаватель МГУ им. М. В. Ломоносова, ulianovalv@gmail.com.

** (c) Бибикова, Л. В. (C) Философия. Журнал Высшей школы экономики. 
Политическая полиция Российской империи - структура, которая была призвана охранять существовавший государственный строй. И хотя в нормативно-правовой базе главная задача Департамента полиции формулировалась как «предупреждение и пресечение преступлений и охрана общественной безопасности и порядка» (Свод законов Российской империи, 1906: 362), общепринятым в современной литературе является представление, казавшееся верным и современникам рубежа XIX-XX вв.: что политическая полиция, в первую очередь, должна была предотвращать революцию и бороться с революционерами.

Однако в литературе отсутствует подробное описание того, какой внутри политического сыска был образ, а точнее, образы революционных событий-того «проекта России», который несла с собой ожидаемая в обществе (и внутри политической полиции) в ближайшем будущем «революция». Не претендуя на полную и окончательную реконструкцию этих образов, попробуем описать и проанализировать некоторые их черты на рубеже XIX-XX вв., то есть в исторический период, предшествовавший началу Первой русской революции.

В историко-теоретической литературе, так или иначе касающейся полиции, нередко предлагается рассматривать политический сыск Российской империи в рамках концепции «полицейского государства»государства, в котором та часть бюрократии, которая связана с полицейскими функциями, играет большую роль в управлении страной в целом ${ }^{1}$. Не отвергая продуктивность этого подхода в отношении политической полиции имперского периода истории России в целом, применительно к обозначенному периоду (конец ХІХ - начало ХХ вв.), как показано в исследованиях последнего времени, деятели политического сыска не имели большого веса среди высшей бюрократии; рекомендации и аналитические записки Департамента полиции нередко игнорировались даже министром внутренних дел, не говоря уже о других инстанциях (Перегудова, 200о; Ульянова, 2009а).

В связи с этим представляется продуктивным в рамках данной статьи дополнить методологию «полицейского государства» концепцией «уликовой парадигмы», разработанной К. Гинзбургом применительно к европейским государствам периода становящегося модерна. Согласно Гинзбургу, в процессе трансформации от традиционного общества к обществу модерна «возникает все более отчетливая тенденция уже

${ }^{1} \mathrm{O}$ концепции «регулярного полицейского государства» см.: Кильдюшов, 2013; Филиппов, 2013; Raeff, 1983 . 
не суммарно-количественного, а качественного и капиллярно-проникающего контроля над обществом со стороны государственной власти» (Гинзбург, Козлова, 2004: 215). При этом итальянский антрополог предложил рассматривать стремление власти к такому «капиллярно-проникающему контролю» над обществом также в связи с развитием в XIX в. медицинских наук, популярности медицинского языка для описания процессов, происходящих в обществе ${ }^{2}$. Гинзбург определяет это через медицинскую семейотику - «дисциплину, которая позволяет, опираясь на поверхностные симптомы», порой ничего не говорящие постороннему наблюдателю, «диагностировать болезни, недоступные для прямого наблюдения» (там же $)^{3}$.

В этом контексте политическая полиция предстает ключевой государственной структурой, которая целенаправленно занималась «диагностикой» состояния общества, обладая для этого широким набором средств (перлюстрация, негласное наблюдение, наружное наблюдение, гласный надзор, секретная агентура и т. д.). И в этой «диагностике» большое место занимал анализ чинами политического сыска тех или иных общественных явлений, свидетельствующих о приближении революции.

При этом в политической полиции отсутствовало внутреннее единство в соответствующем анализе. Разница во взглядах на образ «будущей революции» во многом зависела от структурного контекста, то есть от того, из какого подразделения политического сыска исходил тот или иной документ. Однако дело не столько в функциональных различиях, сколько в мировоззренческих особенностях людей, служивших в той или иной структуре.

Руководящий орган политической полиции - Департамент полиции входил в состав Министерства внутренних дел в качестве одного из подразделений. С момента упразднения в 1880 г. ІІ Отделения Собственной Его Императорского Величества канцелярии кадровая политика в отношении Департамента полиции состояла в целенаправленном привлечении на службу лиц с юридическим образованием и стажем по судебному ведомству ${ }^{4}$. Как пишет крупнейший исследователь политической полиции З. И. Перегудова, «при комплектовании руководящего состава

${ }^{2} \mathrm{O}$ «медикализации» общественного дискурса в ХІХ в. см.: Beer, 2007: 532-537.

3 Об использовании медицинской терминологии в делопроизводственной переписке политической полиции см.: Ульянова, 2009b.

${ }^{4}$ Об этосе судебной корпорации во второй половине XIX в. см.: Уортман, Долбилов и Севастьянов, 2004 . 
Департамента МВД вплоть до 1902 г. стремилось брать в штат преимущественно лиц с юридической подготовкой. Директора Департамента полиции, вице-директора, чиновники особых поручений, прикомандированные к Департаменту, руководители структур (делопроизводств), как правило, имели высшее юридическое образование» (Перегудова, 2000: 337). Помимо пиетета перед законом служащие Департамента полиции - каким бы парадоксальным ни показалось это утверждениеотличались положительным отношением к умеренному либерализму в духе Б. Н. Чичерина, К. Д. Кавелина, А. Д. Градовского 5 .

Совсем иным было мировоззрение служащих местных подразделений политического сыска - губернских жандармских управлений (далееГЖУ). Жандармы, отличавшиеся от обычных военных только окончанием полугодовых курсов при Отдельном корпусе жандармов, были чужды тонкостям политического языка, формировавшегося в России во второй половине XIX в., а вместе с тем-погружены в губернскую и уездную провинциальную жизнь; они мыслили политическое пространство через верноподданнические категории. При этом ГЖУ единственные местные органы политической полиции, существовавшие в каждой губернии и области Российской империи,--были главными информаторами Департамента полиции о положении дел на местах на всем пространстве страны.

Однако ключевую роль в вопросах политического розыска в глазах руководства Департамента играли охранные отделения, существовавшие в наиболее активных центрах революционного движения ${ }^{6}$. В охранных же отделениях, в свою очередь, весомое положение занимали бывшие секретные агенты, знавшие революционное движение изнутри и склонные оперировать языком революционного подполья в делопроизводственной переписке. Среди наиболее известных бывших секретных агентов, ставших успешными «охранниками»,- начальник Московского охранного отделения, автор политики «полицейского социализма» С. В. Зубатов и заведующий Заграничной агентурой П. И. Рачковский, однако ими список отнюдь не исчерпывается (Ульянова, 2009с).

Таким образом, политическая полиция представляла собой совокупность структур, служащие каждой из которых оперировали политическим языком, во многом зависевшим от доминирующего типа ми-

5 О идеях умеренного либерализма см.: Ведерников и др., 1997: 12-25.

${ }^{6}$ До начала XX в. - в Санкт-Петербурге, Москве, Варшаве, с 1902 г. - еще в девяти крупных губернских городах. Сюда же стоит отнести Заграничную агентуру в Париже. 
ровоззрения чинов каждого подразделения, а также задач, стоявших перед данной структурой, и окружающего общественно-политического пространства.

Понятие «революция», если воспользоваться разработанной немецким теоретиком Р. Козеллеком методологией истории понятий, было одним из базовых понятий в дискурсе образованного общества России рубежа хіх-хх вв. Как отмечает Э. Бедекер, неотъемлемой чертой «базовых понятий» является их ориентированность на будущее, проектность содержащихся в них смыслов, а также их способность быть важным инструментом политической борьбы (Бедекер, Дубина, 2010).

В коллективной статье Н. Бульста, Р. Козеллека, К. Майера и Й. Фиша указывается, что одно из ключевых составляющих понятия «революция»-в отличие от понятий «смуты», «бунта», «восстания» и «гражданской войны»- это нацеленность на изменение государственного строя, на принципиальные изменения в политической системе страны (Бульст и др., 2014: 522, 523, 635, 644 и др.). Анализ делопроизводственной переписки служащих политического сыска Российской империи показывает, что под «революцией» понималось, прежде всего, «свержение самодержавия», то есть изменение формы правления с неограниченной власти монарха либо на конституционную монархию, либо на республику (в зависимости от убеждений стремившихся к революции групп).

В политической полиции различали два понятия: «революция» и «революционеры». «Революционерами» считались те, кто готовил свержение существующего строя в подполье, - сюда относилось большое количество нелегальных кружков, партий и групп как социал-революционного, так и социал-демократического толка, борьба политического сыска с которыми подробно была описана еще в советской историографии 7 . Но на благо пришествия «революции» в общероссийском масштабе трудились не только и даже не столько они, сколько общественно-политические группы, находившиеся в легальном пространстве («радикалы», «оппозиционеры», «либералы», «народники», «марксисты») и имевшие доступ к публичным ресурсам (трибуна земского и городского самоуправлений, периодическая печать, публичные лекции, народные чтения, земские школы, съезды врачей и т. п.). Общность из полицейской перспективы подпольного и, по сути, легального

${ }^{7}$ См.: Анисимов, 1989 ; Булдаков и др., 1981; Додонов и Кирьянов, 1990; Карелин, 1968; Павлов, 1989; Революция и общественное движение..., 1986; Самосудов, 1987; Соловьева, 1966; Эренфельд, 1983 . 
противоправительственного движений отразилась в одном из самых популярных и устойчивых словосочетаний, присутствовавших как в делопроизводственной переписке чинов политической полиции, так и в их мемуаристике, - «революционное и оппозиционное движение» ${ }^{8}$.

Донесение начальника Санкт-Петербургского охранного отделения

в Департамент полиции (1893 г.) отражает тонкую грань между легальным и нелегальным в языке полицейского описания революционного движения:

В конце 1890 г. среди некоторых лиц противоправительственного направления возникла мысль об организации кружка из лиц либерального образа мыслей, занимающих общественные должности, преимущественно земских деятелей и земских педагогов, в видах противодействия мероприятиям правительства на законной почве. Не преследуя прямо революционных предприятий, кружок, по мысли его основателей, должен стремиться сплотить всех недовольных и действуя в круге предоставленной им власти и на земских собраниях, или на собраниях ученых обществ, производить давление на правительство посредством петиций, указывающих на необходимость освободительных реформ (курсив мой. - Л. Б.) (О сыне надворного советника..., 1893).

Подобные представления были свойственны всем чинам политического сыска: формально-легальные общественно-политические группы (то есть группы, не запрещенные законом, который в принципе не предполагал наличие публичной политики в самодержавном государстве) воспринимались как серьезная сила, работающая на «свержение самодержавия». О «легальной оппозиции» писали многие служащие Департамента полиции: директора С. Э. Зволянский и А. А. Лопухин, заведующий Особым отделом Департамента Л.А. Ратаев, руководитель 5-го делопроизводства В. К. Лерхе, сотрудник 3-го делопроизводства Н. А. Пешков (О вдове сенатора..., 1893; О дворянине..., 1899; О тверском земстве, 1895). О «легальной агитации» местных революционных кружков интеллигенции писал в январе 1902 г. начальник Владимирского ГЖУ (О совещаниях..., 1901).

${ }^{8} \mathrm{C}$ многочисленными вариациями: «революционные и оппозиционные группы», «революционные и оппозиционные кружки», «революционные и оппозиционные деятели» и т. п. (Новицкий, 1991; Спиридович, 1991; Рууд и Степанов, 1993: 4, 270, 275, 381; Перегудова, 2000: 295-310; Реент, 2002: 248 и далее; Герасимов, 2004; Мартынов, 2004; Заварзин, 2004a,b). 
Вместе с тем в политической полиции полагали, что именно легальное оппозиционное и откровенно противоправительственное общественно-политическое пространство задает основания для развития подпольной и полуподпольной (как различные студенческие кружки) деятельности. Без первых вторые лишились бы существенной подпитки (в том числе финансовой и моральной).

Один из основных лейтмотивов в донесениях жандармов из разных уголков Российской империи в Департамент полиции - это сочувствие и покровительство «революционерам» со стороны «либералов», преимущественно в виде обеспечения работой и финансовой помощи. Например, начальник Орловского ГЖУ в июне 1894 г. писал об известном земском деятеле, писателе, на рубеже 1870-1880-х гг. побывавшем в ссылке,И. П. Белоконском:

Состоящий под негласным надзором полиции с давнего времени, занимающийся по найму статистическими работами при Орловской губернской земской управе дворянин Белоконский [...] жена Валери занимается переводами на русский язык иностранных сочинений. Сестры- $[.$.$] уроками у частных$ лиц [...]. Все эти лица скромностью образа жизни, поведением с видимыми занятиями стараются показать себя во всех отношениях благонадежными, но политическая благонадежность их крайне сомнительна, они тщательно скрывают свои сношения. Ведя знакомство в Орле лишь с одними поднадзорными лицами, но не со всеми вполне откровенны, заявляя себя с некоторыми только либеральными, Белоконские готовы принять у себя и политического нелегального, оказать ему ночной приют и денежную помощь, называя это посильным добрым делом для несчастного (О дворянине..., 1893).

Жандарм из Твери в 1885 г. сообщал в Департамент о местном земском деятеле А. Б. Врасском: «Будучи по своим убеждениям крайне враждебно настроен к существующему порядку в России, Врасский по своим возможностям протежирует и помогает лицам, скомпрометированным в политическом отношении и неблагонадежным, каковыми он и наполнил тверскую губернскую земскую управу» (Политический обзор..., 1885a). Спустя четыре года из этой же губернии в Департамент писали: «Отличаясь редким единодушием и сплоченностью.., тверское земство всегда охотно оказывает поддержу каждому отдельному лицу, где-либо и когда-либо замеченному в политической неблагонадежности, с полною готовностью принимая его на службу, подыскивая ему работу», а

существование, по слухам, секретного вспомогательного фонда, образуемого, будто бы из остатков и сбережений тверского общества взаимного кредита 
и общества Ладо, находящихся в бесконтрольном заведывании политически неблагонадежных лиц-Апостолова, Петрункевичей, Шуянинова, Кащенко и др., привлекают сюда массу поднадзорных из разных мест империи и заставляют их стремиться не в какую-либо другую, а именно в Тверскую губернию с полною и основательною надеждою найти здесь всякого рода сочувствие, нравственную поддержку и материальную помощь (Политический обзор..., 1888).

Охранные отделения также волновали целенаправленные попытки различных «общественных деятелей» выйти на связь с «революционерами». Так, заведующий Заграничной агентурой Департамента полиции в Париже П. И. Рачковский в 1886 г. писал о контактах деятелей «легального пространства» с эмигрантами-народовольцами, жившими в Европе после разгрома «Народной воли» в России в начале 1880-х гг.:

Задуманное было сначала в виде замены неудобного к перевозке в Россию «Вестника» [Народной воли. - Л. Б.] издание периодического революционного листка осложнилось предложением каких-то сочувствующих революционному движению «либералов», которые предлагают будто бы в распоряжение народовольческой группы за границей значительные денежные суммы, с тем чтобы Тихомиров [речь идет о Л. А. Тихомирове.- Л. Б.] перешел из сферы узкоконспиративной деятельности «народовольца» на почву широкого общественного воздействия и заинтересовал бы программой новой газеты все, даже самые умеренные оппозиционные элементы в России (По сообщениям заведующего..., 1886).

Взаимодействие легального и нелегального противоправительственных движений стало темой донесения Рачковского в 1890 г.: при наблюдении за народовольцем П. Л. Лавровым

было [...] установлено, что названный революционер посетил два раза некоего Максима Ковалевского, прибывшего из Москвы 14/26 января [...] Из дальнейших расследований усматривается, что упомянутый Ковалевский, принадлежа к либеральному кружку в Москве, оказывает разные услуги революционерам, сочувствуя вообще революционному движению как за границей, так и в России (По сообщениям заведующего..., 1891).

Позднее, в октябре 1894 г., Рачковский сообщал в Департамент полиции: «Сознавая будто бы важность минуты, русские либералы обратились за содействием к подпольным революционерам, чтобы совместно с ними приступить к действительному разрушению государственного строя России» (Произведения нелегальной печати, 1898). 
При общем понимании, что в по факту легальном политическом поле действуют различные силы, способствующие революции, внутри политической полиции отсутствовало единство в следующем вопросе: какие же из этих легальных общественно-политических сил «работают» на революцию. Служащие ГЖУ включали в число таковых всех, кто в местном сообществе не позиционировал себя как «охранителей». В то же время Департамент полиции относил к тем, кто способствует революции, кроме собственно революционеров-подпольщиков, группы «радикалов», «оппозиционеров» и «радикальных либералов», исключая тем самым «либералов» в целом из «агентов революции» - против чего постоянно возражали в своих донесениях жандармы.

Стратегии жандармов и чинов Департамента полиции заметным образом отличались и в использовании понятия «революция» в качестве риторического инструмента: для оправдания собственных действий (или бездействия), для обоснования тех или иных мер, в карьерных или иных целях. Жандармы были склонны оперировать «революционной угрозой» как актуальной мотивацией для собственной деятельности (или бездействия) в губерниях, для поиска «врагов» в окружающем их обществе.

Показательна риторическая игра, которую вел руководитель Тверского ГЖУ с Департаментом полиции во второй половине 1880-х гг., описывая либеральное движение в подведомственной его надзору губернии в революционных терминах. Так, в политическом обзоре за 1884 г. жандарм характеризовал известного общественного деятеля, видного либерала Ф.И. Родичева:

Крайне вредный и опасный пропагандист, ибо в деле преступной деятельности Русской анархической партии принимает активное участие, что вполне выяснилось дознанием, так как в 1879 г. [...] Софья Перовская, Вера Филлипова, урожденная Фигнер, и другие участники взрыва полотна [...] проживали в имении Родичева (Политический обзор..., 1885b).

Вторил начальнику его помощник в Новоторжском уезде, сообщая о местных либералах:

Линд, обязанный всем Бакуниным, не только усвоил себе их взгляды, но и опередил своих руководителей в слепом озлоблении своем к единодержавной власти [...] если бы не природная трусость Линда и не влияние Бакуниных, благодаря которым Линд в данное время не принимает активного участия 
в злодеяниях русской анархически-террористической партии, то Линд явился бы в рядах террористов исполнителей (Политический обзор..., 1885c).

В 1888 г. аналогичные характеристики были выданы известному либералу М.И. Петрункевичу - это один «из наиболее вредных деятелей в смысле распространения социально-революционного движения по Тверской губернии» (Политический обзор..., 1889). В июне 1889 г. начальник местного ГЖУ в записке о тверском земстве на имя директора Департамента полиции среди участников «социал-революционного движения» называл известных общественных деятелей: братьев П. А. и А. А. Бакуниных, М. П. Литвинова, Д. Н. Квашнин-Самарина, М. И. и И. И. Петрункевичей, В. И. Покровского, Ф. И. Родичева (По сообщениям начальника..., 1888).

В схожем духе почти двадцать лет спустя рассуждал руководитель Черниговского ГЖКУ в политическом обзоре за 1904 г.: «Ненависть к губернатору постоянно подогревается со стороны вожаков либеральной партии всех оттенков... По имеющимся агентурным сведениям против губернатора и вице-губернатора можно ожидать каких-либо террористических актов» (Политический обзор..., 1905).

Однако чины Департамента полиции нередко игнорировали «революционную истерику» представителей местной власти. Характерна история с ярославским губернатором, который, видимо, решил примерить на себя роль сыщика.

В своем донесении министру внутренних дел В. К. Плеве в январе 1904 г. губернатор писал о собственном негласном наблюдении за видным общественным деятелем Д. И. Шаховским через «секретного агента Антонину Прокопьевну», высланную из Баку за участие в местной социал-демократической организации. Губернатор обвинял Шаховского в руководстве Северным комитетом социал-демократической рабочей партии. Свое знакомство с Д. И. Шаховским «агент» описывала следующим образом: он попросил назвать фамилии ее руководителей по социал-демократической организации в Баку. Она назвала Г. М. Ласхишвили, на что Шаховской сказал: «А. Редактор газеты „Цнабич Пурцеи“». Потом «я сказала Дмитрию Ивановичу „возьмите меня для агитации, я хочу мстить за угнетенный народ“». На что он ответил: «Благодарю, у меня сейчас есть трое, пока достаточно». После чего пригласил ее к себе домой на сходку, на которой заявил: «Я получил письмо от сосланных товарищей, они просят денег. У меня нет, я решил обратиться к вам. Друзья, соберем, как и в прошлые года, и пошлем 
не по почте, а с кем-нибудь из наших...». Губернатор предлагал через прокурора Ярославского окружного суда «поймать главных участников во время или по окончании их заседаний» или «произвести в ближайшее время ликвидацию и обыски у всех заподозренных лиц». И получил ответ: «Это философские рассуждения о понятиях русского народа о Боге, Царе и [...] ничего предосудительного в себе не заключают» (О князе..., 1891).

Другой популярной практикой в Департаменте была передача полученной с мест информации в другие ведомства. В 1889 г. после нескольких донесений московского обер-полицмейстера о «тенденциозных» докладах в Юридическом обществе, имевших целью «осмеяние и опошление всех правительственных мер и порядков», Департамент сообщил эти сведения в Министерство народного просвещения, посчитав на этом свою миссию исчерпанной. Московский обер-полицмейстер был другого мнения. Столкновение позиций произошло в переписке о присяжном поверенном Г. А. Джаншиеве, который прочел в феврале 1890 г. доклад «Замечания по поводу организации местных административных и судебных учреждений». Сообщив об этом в Департамент и, видимо, не получив ответа, через четыре месяца обер-полицмейстер обратился к директору Департамента П. Н. Дурново с вопросом о том, не подлежит ли Джаншиев негласному надзору. Ответ Дурново был отрицательным. На этом обер-полицмейстер не успокоился и в очередном сообщении о московском юридическом обществе выразил свое опасение, «чтобы деятельность общества при таком составе его администрации не приняла крайне радикального направления». Дурново и в этот раз не изменил своей позиции:

О вредном направлении деятельности юридического общества в ноябре прошлого г. было сообщено министру народного просвещения, который 29 ноября 1889 г. уведомил [...] о сделанном председателю юридического общества через попечителя учебного округа в предостережении, что в случае допущения к прочтению в заседаниях общества рефератов тенденциозного характера, общество будет закрыто. В виду сего в настоящее время не встречается надобности в каких-либо распоряжениях по отношению к упомянутому обществу. K обязанности полиции надлежит лишь отнести наблюдение за происходящими в обществе чтениями, с тем, чтобы обо всем заслуживающим внимания своевременно доводилось до сведения Департамента (О московском юридическом обществе, 1889).

Для Департамента полиции дискурс «революционной угрозы» становится актуальным в начале хх в. (в 1901-1904 гг.), отражая тем 
самым скорее реальное общественно-политическое развитие страны, чем практику «дискурсивных игр».

Особенное внимание при этом чины Департамента и вместе с ним охранных отделений уделяли «радикалам». Это течение практически не известно в литературе об общественном движении, но, видимо, является аутентичным восприятию современников определенного общественно-политического сегмента. Один из общественных деятелей, В. Кранихельд, так описывал «радикалов» 1890-х гг. в 1917 г.:

Казалось, я попал в общество людей, которым жизнь уже не сулила в будущем ничего неизведанного, заманчивого, не открывала перед ними никаких перспектив. А между тем это были в большинстве люди молодые, студенты, только недавно еще потерпевшие на своем жизненном пути некоторую и, в сущности, незначительную аварию. Несчастие их заключалось однако в том, что вместе с этой личной аварией терпело крушение также их миросозерцание-рушились их идеалы, их вера в будущее. И чем круче подламывала жизнь их старые верования, тем нетерпимее относились они ко всем инакомыслящим, по-сектантски замыкаясь в свой маленький тесный кружок. Они добывали себе пропитание грошевыми уроками, называли себя «радикалами» и с особенной брезгливостью отзывались о местном культурном обществео либералах и либералишках (Кранихельд, 1917: 233).

Наиболее близкой к «радикалам» (и в то же время четко дистанцированной в восприятии полицейских) группой в легальном общественно-политическом пространстве были «либералы», о чем свидетельствуют многочисленные упоминания о «либеральных и радикальных кружках», «либеральной и радикальной публике», «либеральной и радикальной группах», «либеральной части общества и радикальной молодежи», «либерально-прогрессивной и радикальной фракциях» и пр. 9 При этом «радикалы» нередко использовали «либералов» для попадания в легальное пространство и для создания себе публичных площадок. Так, начальник Московского охранного отделения С. В. Зубатов писал в 1901 г. о «близоруких либералах» в обществе взаимопомощи лиц интеллигентных профессий:

Дабы образовать так или иначе прочный и сильный комплот, радикалы, прикрываясь идеей взаимопомощи, привлекли к содействию некоторых близоруких либералов, политическая благонадежность коих не могла бы внушать подозрений, а затем, оформив при их помощи дело и собравшись в достаточном числе, сначала устранили на чрезвычайном общем собрании 16 марта

${ }^{9}$ Например, см.: О состоящих..., 1893. 
прошлого года учредительный декорум и ввели в совет общества своих сторонников, а потом, к концу года, окончательно завладели его административными органами (О закрытии..., 1901).

При этом кажется правомерным утверждать, что умеренный либерализм и либерально-консервативные взгляды в Департаменте оценивались как «норма», а не как политическая «угроза». В делопроизводственной переписке главного «охранительного ведомства» вряд ли можно найти откровенные высказывания по этому поводу, однако некоторые косвенные «улики» позволяют сделать такой вывод. Так, директор Департамента Н. А. Петров на перлюстрированном письме известного журналиста Г. К. Градовского в Лондон в 1894 г. сделал такую помету: «Умеренный либерал. Можно не наблюдать» (). Деятели земского самоуправления ассоциировались в Департаменте полиции и в Московском охранном отделении с «умеренным либерализмом», причем полицейские чины полагали, что «радикалы» их используют «втемную» для раскачивания ситуации. Заведующий Особым отделом Департамента Л. А. Ратаев отмечал в 1902 г.:

За спинами увлекающихся и протестующих земцев всегда стоит в качестве подсказчика земский статистик, земский писарь, земский врач, агроном и т. п. В одной губернии земские учреждения находятся под давлением заведывающего земским санитарным бюро, в другом вдохновителем является главный статистик, в третьем - заведующий по вольному найму страховым отделом и т. д. (О легальной опозиции, 1902).

Начальник Московского охранного отделения В. В. Ратко и вовсе находился под влиянием неославянофильского течения, связанного с именем известного земца Д. Н. Шипова. В записке, датируемой февралем 1905 г., положительно характеризуя «политику доверия» министра внутренних дел П. Д. Святополк-Мирского в противовес политике его предшественника В. К. Плеве, Ратко, по сути, воспроизвел некоторые постановления земского съезда ноября 1904 г. в версии сторонников Д. Н. Шипова.

Для предотвращения надвигающейся катастрофы необходимо безотлагательно: 1. дать возможность умеренным общественным элементам применить свои силы в деле служения государству и участия в законодательных работах, наряду с правительственными чиновниками (обусловив эту меру имущественным цензом) [...] 3. пересмотреть уставы высших учебных заведений, предоставив принять участие в обсуждении этого вопроса представителям от профессуры в высших учебных заведениях (Записки начальников..., 1904) ${ }^{10}$.

${ }^{10} \mathrm{O}$ постановлениях ноябрьского земского съезда 1904 г. см.: Второй съезд..., 1904. 
В начале хх в. для Департамента полиции именно «радикализм» стал главной легальной угрозой с точки зрения расползания революционных настроений за пределы подполья, в широкие слои общества. В 1901 г. руководство политического сыска дало определение тому спектру общественно-политических деятелей, которые легально трудились на благо «пришествия революции». Толчком к этому стали события 4 марта 1901 г. Тогда студенческая демонстрация у Казанского собора в Санкт-Петербурге была разогнана полицией, что вызвало волну негодования в среде интеллигенции.

Заведующий Особым отделом Департамента полиции (ключевой аналитической структуры политического сыска) Л. А. Ратаев и руководитель Департамента С. Э. Зволянский писали в записке о событиях, связанных со студенческой демонстрацией:

Выяснены все главнейшие деятели радикально-оппозиционной группы, захватившей за последние два года руководство всем революционным движением в Петербурге и ознаменовавшей свою деятельность за последнее время подстрекательством учащейся молодежи и рабочих к устройству уличных манифестаций, а либеральной части общества к предъявлению правительству разных неосновательных и неподлежащих удовлетворению требований (Внутренняя агентура, 1898).

В другом месте Ратаев отмечал, что состоящие в «радикально-оппозиционной группе» добиваются «низвержения в более или менее отдаленном будущем существующего ныне в империи государственного строя» (Свод данных..., 1898). Более развернутое определение «радикально-оппозиционной группы» было сформулировано в циркуляре № 6234 (июнь 1901 г.), составленном в Департаменте полиции и разосланном губернаторам, градоначальникам, обер-полицмейстерам и начальникам ГЖУ от имени и за подписью министра внутренних дел Д. С. Сипягина: группа

лиц, преимущественно интеллигентных профессий, которые, не принимая непосредственного участия и даже намеренно устраняясь от активной революционной деятельности, поставили себе задачей, путем устройства вечеринок, чтения речей и рефератов на соответствующие темы, а также издательства систематически подобранной тенденциозной литературы, подготовлять в среде молодежи и рабочих противоправительственных деятелей и агитаторов $(\mathrm{O}$ профессоре..., 1893).

В историографии начало Первой русской революции традиционно датируется 9 января 1905 г., однако для чинов политической полиции 
революция началась в конце 1904 г. - с так называемой «банкетной кампании», когда по всей стране прокатились публичные мероприятия в честь 40-летия судебной реформы, сопровождавшиеся «крайне антиправительственными» речами. Публичное пространство оказалось захвачено революционным дискурсом. Причина этого, по мнению чинов политического сыска, состояла в объединении подпольщиков с тем спектром общественного движения, который в Департаменте называли «легальной оппозицией». Так, в записке от ноября 1904 г. чиновник Департамента полиции Н. Д. Зайцев отмечал:

зо сентября в Париже по инициативе финляндской оппозиции состоялась конференция революционных и оппозиционных групп, решивших заключить союз для ведения общими силами в настоящее тяжелое [...] время борьбы с самодержавным режимом, причем русская либеральная партия (бывшая группа русских конституционалистов или освобожденцев Петра Струве) постановила продолжать свои действия на легальной почве в земских и общественных учреждениях (О помощнике..., 1894).

Накануне демонстрации освобожденцев, социал-демократов и социал-революционеров 5 и 6 декабря 1904 г. начальник Московского охранного отделения Ратко писал: «Сделано все для создания революционного настроения и сознания, что самое главное, полной безнаказанности. Цинизм либералов и нахальство революционеров дошло до максимума, и, кажется, уже дальше идти нельзя» (цит. по: Козьмин, 1928: 41).

$$
* * *
$$

Попытка удержать стремительно сползающее в революцию публичное пространство в начале Xх в. отразилась в практике личных переговоров чинов Департамента полиции с теми, кто это публичное пространство активно осваивал и «революционизировал». В отношении особо маститых деятелей оппозиционного движения или в особо тревожных ситуациях Департамент практиковал вызовы к директору или к министру внутренних дел. Так, в 1903 г. на беседу к министру внутренних дел был вызван Д. И. Шаховской, который был одной из самых серьезных проблем для жандармов Твери и Ярославля на протяжении около двадцати лет. При этом начальник Ярославского ГЖУ, который в течение предшествующего десятилетия неоднократно просил головную структуру политического сыска об избавлении губернии от Шаховского, получил из Департамента полиции такое письмо:

По приказанию господина министра имею честь уведомить, что предположения Ваши о необходимости высылки из пределов Ярославской губернии 
признаны заслуживающими уважения. Но император во внимание к заслугам его отца и сестры повелел соизволить приостановиться внесением означенного дела в Особое совещание и, вызвав князя Шаховского в СанктПетербург, объявить ему, что дальнейшее участие его в агитации, происходящей в неблагонадежной части общества, поведет к высылке в одну из отдаленных местностей (О князе..., 1903а $)^{11}$.

Одновременно с Шаховским были вызваны для «личных объяснений» несколько его соратников (О князе.., 1903 b).

После нелегального майского земского съезда 1902 г. его организаторы Д. Н. Шипов и М. А. Стахович были вызваны к министру В. К. Плеве, который стремился договориться с Шиповым о содействии власти со стороны так называемой «общественности» (Шацилло, 1985: 136-139). В конце 1902 г. в преддверии банкета, посвященного 20о-летию печати, Плеве вызывал для личной беседы маститого народника Н. К. Михайловского, а директор Департамента полиции А. А. Лопухин - общественных деятелей Н. А. Рубакина, В. И. Чарнолусского, Г. А. Фальборка и С.А. Вейнберга. Целью властей являлось заключение «сделки» о форме банкета: он мог быть разрешен при условии отсутствия речей о конституции и адреса в этом духе (там же: 55).

Таким образом, в первые годы хх в. у чинов политической полиции всех уровней представление о надвигающейся «революции» приобретает устойчивую форму, а самым явным ее предвестником становится попадание революционного дискурса в публичное общественно-политическое пространство.

Отдельной темой, важной для служащих политической полиции, было содержание «будущей революции». Из делопроизводственной переписки ясно, что жандармы видели главную цель всех революционных сил в «освобождении» с анархической подкладкой: установлении «свободы» во всех ее возможных проекциях - начиная от комплекса «политических свобод》 и неконтролируемого публичного пространства общественных дискуссий и заканчивая отсутствием дисциплины в учебных заведениях и моральных норм в частной жизни. В этом смысле жандармы были ближе к сугубо «охранительному дискурсу», представленному фигурами К. П. Победоносцева, М. Н. Каткова, В. А. Грингмута, В.П. Мещерского и трактовавшего «революцию» как нацеленное на сугубо политическое действие.

${ }^{11} \mathrm{O}$ вызове Д. И. Шаховского к министру В. К. Плеве см.: Шацилло, 1985: 95. 
В Департаменте полиции же, с одной стороны, были склонны трактовать возможную в будущем «революцию» как следствие социальной неудовлетворенности низов, отсутствия легального публичного пространства для развития низовой самоорганизации. Во многом в этом представлении берет корни поддержка так называемой политики полицейского социализма, осуществлявшейся разными директорами Департамента полиции и приведшей к карьерному росту ее автора С. В. Зубатова из начальников Московского охранного отделения в заведующие Особым отделом Департамента полиции.

С другой стороны, чины Департамента настойчиво писали в первые годы хх в. о том, что революция неизбежна при сохраняющейся слабости системы власти, отсутствии единства во властной системе, внутренних колебаниях, а также при следовании и-более категоричнопотакании общественному мнению. В результате с полицейской перспективы размывались границы допустимого политического поведения и критерии, по которым легальное пространство могло быть ограничено от проникновения «революционных настроений». Заведующий Особым отделом Департамента полиции Л. А. Ратаев писал об этом в 1902 г.:

Позволю себе коснуться [...] вопроса [...] о крайней податливости к ходатайствам за революционеров разных высокопоставленных лиц. Обыкновенно эти лица совершенно не знают или очень мало знают тех людей, за которых просят, а действуют в громадном большинстве случаев по чужим ходатайствам. Добившись освобождения или прощения их протеже, высокопоставленные лица, рассыпавшись в благодарностях, возвращаются в свою среду и там в интимных беседах весьма не благоприятно отзываются о направлении Министерства внутренних дел, вполне логично по своему рассуждая, что если бы лицо, за которое они просили, было действительно виновато, то не помогли бы никакие просьбы, между тем стоило сказать слово и вот [...] Следовательно, государственная полиция действует зря, без достаточных оснований. В таком же виде слухи о деятельности государственной полиции доходят до двора, а оттуда восходят далее (О легальной оппозиции, 1902).

Начальник Московского охранного отделения С. В. Зубатов размышлял в связи со скандалом вокруг спектакля «Контрабандисты» в театре А. С. Суворина: во время премьеры спектакля студенты под влиянием кружка князя В.В. Барятинского устроили беспорядки в зале, после чего местная власть распорядилась о снятии пьесы из репертуара. С. В. Зубатов, предчувствуя снятие пьесы, писал:

Индифферентизм к таким вещам может легко породить полный политический разврат. Спустить этот инцидент-значит, расписаться в полученной оплеухе. 
Кто же власть? Кто охраняет право частных лиц и групп как не власть? Не голое ли насилие учинили скандалисты над Сувориным, театром и артистами, получившими от установленных властей п рав о [разрядка в тексте. - Л. Б.] на постановку пьесы. Если власть окажется бессильной защитить от них дарованное ею право, то, что же Россия - отживающая страна. Накануне она что ли переворота? [...] Да ведь это бездействие власти-приведет в уныние всякого благонамеренного человека и даже озлит его: не повиноваться же в самом деле шайке мальчишек с деканатами-руководителями во главе. Нет, надо виновных вздуть, да покрепче, а то раскачаете и другие города [...] Неужели пьесу снимут? Ведь это показать свое бессилие- опасная вещь для будущего (Внутренняя агентура, 1898).

Отсутствие внятного курса власти, ее колебания вслед за общественными настроениями воспринимались внутри политического сыска как главная угроза, способствующая скорому «пришествию» революциии этот аргумент был одним из наиболее популярных во внутренней переписке ее деятелей как перед Первой русской революцией, так и накануне 1917 г.

При этом деятели политического сыска еще до начала Первой русской революции психологически жили с ощущением скорого и практически неотвратимого наступления революционной поры. Внутренние же различия сводились к разнице в представлениях о том, по каким причинам эта пора наступит. Жандармы со свойственными им антипрогрессорскими настроениями, по большей части, были склонны винить в предстоящей революции современное им общество, нежелающее жить в верноподданнической, а значит, досовременной парадигме мироустройства. Чины же Департамента полиции и некоторые деятели охранных отделений скорее возлагали ответственность за будущий революционный взрыв на власть, бесконечно колеблющуюся на протяжении предшествующего полувека между стремлением сохранить традиционные для самодержавия политические формы и настойчивым и неумолимым прогрессизмом «образованного меньшинства».

Таким образом, обобщая (и неизбежно упрощая), можно утверждать, что внутри системы политической полиции сложилось два образа «революции», которые в общем и целом соответствуют двум понятиям «революция», описанным Р. Козеллеком. Первый: революция - это сугубо политическое явление, связанное с изменением основ государственного строя (что, собственно, и произошло в 1905 г.): в рамках методологии истории понятий, таким и было изначальное смысловое наполнение этого термина. Второй же образ «революции» в Европе 
возник ближе к середине хІх в.; в частности, в Германии появилось различение «политической революции», которая касалась государственно-гражданской, конституционно-правовой стороны, и «социальной»касавшейся общества (Бульст и др., 2014: 699). Анализ делопроизводственной переписки политического сыска Российской империи рубежа XIX-XX вв. показывает, что руководству политической полиции (то есть чинам Департамента полиции) к началу хх в. был ближе именно такой образ революции. В этом смысле события революционного 1905 г. имели для них первостепенное значение не столько с точки зрения изменения государственного строя (как было для жандармов), сколько как неизбежное отражение трансформационных процессов, имевших место в российском обществе.

\section{СОКРАШЕНИЯ}

ГАРФ Государственный архив Российской Федерации.

\section{Источники}

\section{РукоПИСНЫЕ ИСточники}

Внутренняя агентура. Агентурные сведения из Москвы. Л. 192-193. Переписка // ГАРФ. - 1898. - Ф. 102. - Особый отдел. - 1898. - Д. 2. - Ч. 1. - Лит. В. Внутренняя агентура. Личное и денежное дело сотрудника М.И. Харьковцева. Л. 64. Записка // ГАРФ. - 1898. - Ф. 102. - Оп. 316. - 1898 . Д. 2. - Ч. 5. - Т. 1.

Записки начальников охранных отделений о революционных организациях в их районах. Л. 48. Записка начальника Московского отделения по охранению общественной безопасности. О постановлениях ноябрьского земского съезда 1904 г. // ГАРФ. - 1904. - Ф. 102. - Особый отдел. - 1904. - Д. 1195.

О вдове сенатора тайного советника Александре Михайлове Калмыковой. Л. 6. Справка // ГАРФ. - 1893. - Ф. 102. - 3 делопроизводство. - 1893. - Д. 1200.

О дворянине Иване Петрове Белоконском. Л. 69-7о. Донесение начальника Орловского жандармского управления // ГАРФ. — 1893. - Ф. 102. - 3 делопроизводство. - 1893. - Д. 820.

О закрытии Московского Общества взаимопомощи лиц интеллигентных профессий. Л. 2, 6. Донесение // ГАРФ. - 1901. - Ф. 102. - 3 делопроизводство. - 1901. - Д. 933.

О князе Дмитрии Иванове Шаховском, обвиняемом в политической неблагонадежности. Переписка // ГАРФ. - 1903а. - Ф. 102. - 7 делопроизводство. 1903. - Д. 1791. - Л. 93. 
О князе Дмитрии Иванове Шаховском, обвиняемом в политической неблагонадежности. Переписка // ГАРФ. - 1903b. - Ф. 102. - 7 делопроизводство. 1903. - Д. 1791. - Л. 49-53.

О князе Дмитрии Ивановиче Шаховском. Переписка // ГАРФ. - 1891. Ф. 102. - 3 делопроизводство. - 1891. - Д. 527. Т. 1. - Л. 152, 153. T. 2. - Л. $12,82-103$.

О легальной оппозиции. Л. 3 об.-4. Записка для памяти // ГАРФ. - 1902. Ф. 102. - Особый отдел. - 1902. - Д. 835.

О легальной оппозиции. Л. 7. Записка для памяти // ГАРФ. - 1902. - Ф. 102. Особый отдел. - 1902. - Д. 835 .

О московском юридическом обществе. Л. $7,11,13^{-14}, 15^{-16}$. Переписка // ГАРФ. - 1889. - Ф. 102. - 3 делопроизводство. - 1889. - Оп. 87. - Д. 503.

О помощнике присяжного поверенного Петре Бернгардове Струве. Л. 162а. Записка // ГАРФ. - 1894. - Ф. 102. - 3 делопроизводство. - Оп. 92. 1894. - Д. 202.

О профессоре Санкт-Петербургского университета Петре Францеве Лесгафте. Л. 58. Циркуляр // ГАРФ. - 1893. - Ф. 102. - 3 делопроизводство. 1893. - Оп. 91. - Д. 434.

О совещаниях в декабре 1901 г. и январе 1902 г. под председательством господина директора Департамента полиции начальников некоторых губернских жандармских управлений, в районах коих замечается особое развитие революционной пропаганды. Л. 64. Донесение начальника Владимирского жандармского управления // ГАРФ. - 1901. - Ф. 102. - Особый отдел. - 1901. - Д. 987.

О состоящих при Императорском Вольном Экономическом обществе Санкт-Петербургском и Московском комитетах Грамотности. Л. 120, 138-143. Переписка // ГАРФ. - 1893. - Ф. 102. - 3 делопроизводство. - 1893. Оп. 91. - Д. 635 .

О сыне надворного советника Генрихе Адольфове Фальборке. Л. 6. Справка // ГАРФ. - 1893. - Ф. 102. - 3 делопроизводство. - 1893. - Д. 1199.

О тверском земстве. Всеподданнейший отчет. Л. $3^{-16} / /$ ГАРФ. - 1895. Ф. 102. - 3 делопроизводство. - 1895. - Д. 1719.

По сообщениям заведующего Парижской агентурой и по переписке с ним. Л. 280-281. Донесение // ГАРФ. - 1886. - Ф. 102. - 3 делопроизводство. Оп. 82. - 1886. - Д. 93.

По сообщениям заведующего Парижской агентурой и по переписке с ним. Л. 69-69 об. Донесение // ГАРФ. - 1891. - Ф. 102. - 3 делопроизводство. 1891. - Д. 1.

По сообщениям начальника Тверского губернского жандармского управления. Л. 87-89. Донесение // ГАРФ. - 1888. - Ф. 102. - 3 делопроизводство. 1888. - Оп. 84. - Д. 235. 
Политический обзор по Тверской губернии. Политический обзор // ГАРФ. 1885a. - Ф. 102. - 3 делопроизводство. - Оп. 81. - 1885. - Д. 59. Ч. 40. - Л. 2.

Политический обзор по Тверской губернии. Политический обзор // ГАРФ. 1885b. - Ф. 102. - 3 делопроизводство. - 1885. - Д. 59. - Ч. 40. - Л. 4.

Политический обзор по Тверской губернии. Политический обзор // ГАРФ. 1885c. - Ф. 102. - 3 делопроизводство. - 1885. - Д. 59. - Ч. 40. - Л. $3^{2 .}$

Политический обзор по Тверской губернии. Политический обзор // ГАРФ. 1888. - Ф. 102. - 3 делопроизводство. - 1888. - Д. 89. - Ч. 32. - Л. 2.

Политический обзор по Тверской губернии. Политический обзор // ГАРФ. 1889. - Ф. 102. - 3 делопроизводство. - 1889. - Д. 43. - Ч. 29. - Л. 11, 12.

Политический обзор по Черниговской губернии. Л. 15. Политический обзор // ГАРФ. - 1905. - 102. - Особый отдел. - 1905. - 1 отделение. - Д. 106. Ч. 11.

Произведения нелегальной печати. Сношения членов Лондонской группы с кружком санкт-петербургских либералов, намеревающихся издавать в Лондоне свой специальный орган «Земский собор». Л. 2 об. Донесение заведующего Заграничной агентурой // ГАРФ. - 1898. - Ф. 102. - Особый отдел. 1898. - Оп. 226. - Д. 14. - Ч. 6.

Свод данных Департамента Полиции о проявлениях борьбы против правительства на легальной почве в Санкт-Петербурге. Л. 2. Записка для памяти // ГАРФ. - 1898. - Ф. 102. - Особый отдел. - 1898. - Д. 723.

\section{ОПУвЛИКОВАННЫЕ ИСТОЧНИКИ}

Второй съезд земских деятелей. - СПб., 1904. - 6-9 ноября 1904.

Герасимов A. B. На лезвии с террористами // Охранка. Воспоминания руководителей политического сыска. В 2 т. Т. 2. - М. : Новое литературное обозрение, 2004.

Мартынов А.П. Моя служба в Отдельном корпусе жандармов // Охранка. Воспоминания руководителей политического сыска. В 2 т. Т. 1. - М. : Новое литературное обозрение, 2004.

Новичкий В. Д. Из воспоминаний жандарма. - М. : Издательство МГУ, 1991.

О дворянине Михаиле Иванове Туган-Барановском. Л. 157. Справка // ГАРФ. 1899. - Ф. 102. - 3 делопроизводство. - 1899. - Д. 1055.

Свод законов Российской империи. Т. 1. Ч. 2. - СПб., 1906.

Сnиридович A. Записки жандарма. - М. : Художественная литература, 1991.

Заварзин П. П. Жандармы и революционеры // Охранка. Воспоминания руководителей политического сыска. В 2 т. Т. 2. - М. : Новое литературное обозрение, 2004 а.

Заварзин П. П. Работа тайной полиции // Охранка. Воспоминания руководителей политического сыска. В 2 т. Т. 1. - М. : Новое литературное обозрение, $2004 \mathrm{~b}$. 


\section{ЛИТЕРATУРA}

Анисимов Н. Н. Борьба большевиков против политической тайной полиции самодержавия (1903-1917). - 1989 .

Бедекер Э. Размышления о методе истории понятий / пер. с нем. В. Дубиной // История понятий, история дискурса, история метафор. - М. : Новое литературное обозрение, 2010. - С. $34^{-65}$.

Борьба за массы в трех революциях в России: Пролетариат и средние городские слои / В.П. Булдаков [и др.]. - М. : Мысль, 1981.

Ведерников В.В., Китаев В.А., Луночкин А.В. Конституционный вопрос в русской либеральной публицистике 6o-80-х гг. ХІХ в. - М. : Магистр, 1997.

Гинзбург K. Мифы-эмблемы-приметы: морфология и история / пер. с итал. С. Л. Козловой. - М. : Новое литературное обозрение, 2004.

Додонов Б. Ф., Киръ.янов Ю. И. Обзор архивных источников об основных формах массового рабочего движения в России, 1895 - февраль 1917. - М., 1990.

Карелин А. П. Русский полицейский социализм // Вопросы истории. - 1968. № $10 .-$ C. $41^{-}-58$.

Кильдюшов О.В. Полиция как наука и политика: о рождении современного порядка из философии и полицейской практики // Социологическое обозрение. - 2013. - Т. 12, № 3. - С. 9-40.

Козъмин Б. П. С. В. Зубатов и его корреспонденты. Среди охранников, жандармов и провокаторов. - М., Ленинград : Государственное издательство, 1928.

Кранихельд В. В. Я. Яковлев-Богучарский (по материалам Департамента полиции, Московского охранного отделения и по личным воспоминаниям) // Былое. - 1917. - Т. 23, № 1 .

Павлов Б. Д. Эсеры-максималисты в Первой русской революции. - М. : Издательство Всесоюзного заочного политехнического института, 1989.

Перегудова З. И. Политический сыск России. - М. : Российская политическая энциклопедия, 2000.

Революция и общественное движение в Сибири в конце XIX - начале XX в. Новосибирск : Наука, 1986.

Реент Ю. А. Полицейская система Российской империи начала Хх в. (1900-1917) : дис. ... д-ра ист. наук : 07.00.02 / Реент Ю. А. - М. : Московский государственный университет, 2002.

Рууд Ч., Степанов С. Фонтанка, 16. - М. : Мысль, 1993.

Самосудов В. М. Большевики Сибири в борьбе против царизма (1894- февраль 1917 г.) - Иркутск : Издательство Иркутского университета, 1987.

Словарь основных исторических понятий : избранные статьи. В 2 т. Т. 1. Революция (Revolution), бунт, смута, гражданская война (Rebellion, Aufruhr, Bürgerkrieg) / Н. Бульст [и др.] ; сост. Ю. Зарецкого, К. Левинсона, И. Ширле ; пер. с нем. К. Левинсон. - М. : НЛО, 2014. - С. 520-728.

Соловъева М. В. Царские провокаторы и дело социал-демократической фракции II Государственной Думы // Вопросы истории. - 1966. - № 8. 
Улъянова (Бибикова) Л. В. «Обезвредить хирургическими мерами нельзя»: либеральное движение глазами политической полиции (1880-1905 гг.) // Траектория в сегодня: россыпь историко-биографических артефактов. - Челябинск : Энциклопедия, 2009а. - С. 232-247. - К юбилею профессора И. В. Нарского. Ульянова (Бибикова) Л.В. Политическая полиция и либеральное движение, 1880-1905 гг. : дис. ... канд. ист. наук : 07.00.02 / Ульянова (Бибикова) Л. В. М. : Московский государственный университет, 2009b.

Ульянова (Бибикова) Л. В. Социально-профессиональный портрет политической полиции Российской империи (1880-1905) // Вестник Пермского университета. - 2009с. - Т. 9, № 2. - С. 92-101.

Уортман Р. Властители и судии: развитие правового сознания в императорской России / пер. с англ. М.Л. Долбилова, Ф.Л. Севастьянова. - М. : Новое литературное обозрение, 2004.

Филиппов A.Ф. К исторической ситуации полиции в России // Социологическое обозрение. - 2013. - Т. 12, № 2. - С. 41-42.

Шаиилло К. Ф. Русский либерализм накануне революции. - М. : Наука, 1985. Эренфельд Б. К. Тяжелый фронт. Из истории борьбы большевиков с царской тайной полицией. - М. : Политиздат, 1983.

Beer D. "Microbes of the Mind": Moral Contagion in Late Imperial Russia // The Journal of Modern History. - 2007. - No. 79. - P. 532-537.

Raeff $M$. The Well-Ordered Police State: Social and Institutional Change through Law in the Germanies and Russia, 1600-1800. - Yale University Press, 1983.

Bibikova, L. V. 2018. "Politicheskaya politsiya kontsa XIX - nachala XX vv. i 'revolyutsiya': igra ponyatiyem ili real'naya ugroza? [The Political Police at the Turn of the Twentieth Century and the 'Revolution': A Game of Concept or the Real Threat?]" [in Russian]. Filosofiya. Zhurnal Vysshey shkoly ekonomiki [Philosophy. Journal of the Higher School of Economics] II (2), 70-98.

LYUBOV' BIBIKOVA

PhD in History, Senior LeCturer at the Lomonosov Moscow State University

\section{The Political Police at the Turn of the Twentieth CEnTURY AND THE "Revolution": A Game of Concept or the Real Threat?}

Abstract: This article is concerned with the interpretation of the concept of revolution by various structures of the political police of the Russian Empire of the late 19th - early 2oth centuries (Department of police, security departments, provincial gendarmerie management) the union of state institutions which had to fight the revolution. In the frames of the history of concepts developed by R. Kozellek, attention is drawn to the fact that the revolution alike the concepts of troubles, revolt, uprising, and civil war is aiming at changing of the state 
system, on fundamental transformations in the political system of the country. The theoretical framework for the explication of this approach to the records of political investigation is the concept of evidence paradigm proposed by K. Ginzburg to describe the process of the formation of state control over society in the European countries of the period of becoming Modern. According to the officials of the political police of the Russian Empire, revolutionaries were those who aimed to overthrow the existing system; those who belonged to the underground resistance. But they were not those who did the most for the benefit of the revolution on an all-Russian scale - not compared to the socio-political groups that existed in the legal space and had access to the publicity. At the same time, gendarmes regarded everyone, who did not consider himself an ohranitel (Russian for conservator) as a representative of revolutionary legal socio-political forces. The Police Department of Russia regarded not only underground revolutionaries themselves to be a revolutionary threat, but also the radicals, the opposition members, and the radical liberals; liberals in general, though, were not considered to be the agents of the revolution. Two images of revolution, which were formed within the system of the political police, in general correspond with the two concepts of revolution, described by $R$. Kozellek. In the first, which is chronologically younger, revolution is considered to be an exclusively political phenomenon concerned with the change of the bases of a state system (which actually occurred in 1905). The second image of the revolution, which originated in Europe in the middle of the 19th century, suggested the distinction of political revolution (i.e. one that is concerned with the state-civil, constitutional and legal side) and social revolution (concerned with the society). Analysis of the correspondence of the political investigation forces of the Russian Empire at the turn of the 19th-2oth centuries shows that this image of the revolution resonated with the leadership of the political police (i.e. the officials of the Department of police) by the beginning of the 2oth century. In this sense, the events of the revolutionary 1905 year had primary importance for them not so much in terms of changes in the state system (as it was for the gendarmes), but as an inevitable reflection of the transformational processes that took place in the Russian society.

Keywords: Russian Political Police, the Concept of Revolution, Police Department of Russia, Gendarmerie, History of Ideas, Radicalism, Ruling Elites of the Russian Empire.

DOI: $10.17323 / 2587-8719-2018-I I-2-70-98$.

\section{REFERENCES}

Anisimov, N. N. 1989. "Bor'ba bol'shevikov protiv politicheskoy taynoy politsii samoderzhaviya (1903-1917) [The Struggle of Bolsheviks with the Political Secret Police of the Autocracy (1903-1917)]" [in Russian]. (Sverdlovsk).

Bedeker, E. [Bödeker, H.E.] 2010. "Razmyshleniya o metode istorii ponyatiy [Ausprägungen der hist orischen Semantik in den historischen Kulturwissenschaften]" [in Russian]. In Istoriya ponyatiy, istoriya diskursa, istoriya metafor [Begriffs-geschichte, diskurs-geschichte, metaphern-geschichte], trans. from the German by V. Dubina, 34-65. Moskva [Moscow]: Novoye literaturnoye obozreniye.

Beer, D. 2007. "'Microbes of the Mind': Moral Contagion in Late Imperial Russia." The Journal of Modern History, no. 79: 532-537.

Buldakov, V. P., et al. 1981. Bor'ba za massy v trekh revolyutsiyakh v Rossii: Proletariat $i$ sredniye gorodskiye sloi [The Fight for the Masses in Three Russian Revolutions: Proletariat and Urban Middle Class] [in Russian]. Moskva [Moscow]: Mysl'.

Dodonov, B.F., and Yu. I. Kir'yanov. 1990. Obzor arkhivnykh istochnikov ob osnovnykh formakh massovogo rabochego dvizheniya $v$ Rossii, 1895-fevral' 1917 [Review of the 
Principal Archival Sources on the Main Forms of Mass Labor Movement in Russia, 1895 - February 1917] [in Russian]. Moskva [Moscow].

Erenfel'd, B. K. 1983. Tyazhelyy front. Iz istorii bor'by bol'shevikov s tsarskoy taynoy politsiyey [A Difficult Front. From the History of the Struggle of the Bolsheviks and the Tsarist Secret Police] [in Russian]. Moskva [Moscow]: Politizdat.

Filippov, A.F. 2013. "K istoricheskoy situatsii politsii v Rossii [On the Historical Situation with the Police in Russia]" [in Russian]. Sotsiologicheskoye obozreniye [Russian Sociological Review] 12 (2): 41-42.

Gerasimov, A. V. 2004. "Na lezvii s terroristami [On the Edge with the Terrorists]" [in Russian]. In vol. 2 of Okhranka. Vospominaniya rukovoditeley politicheskogo syska [Okhrana. Memoirs of the Domestic Intelligence Head Officers]. 2 vols. Moskva [Moscow]: Novoye literaturnoye obozreniye.

Ginzburg, K. 2004. Mify-emblemy-primety: morfologiya i istoriya [Miti, emblemi, spie. Morfologia e storia] [in Russian]. Trans. from the Italian by S. L. Kozlova. Moskva [Moscow]: Novoye literaturnoye obozreniye.

Karelin, A. P. 1968. "Russkiy politseyskiy sotsializm [Russian Police Socialism]" [in Russian]. Voprosy istorii [Issues of History], no. 10: 41-58.

Kil'dyushov, O. V. 2013. "Politsiya kak nauka i politika: o rozhdenii sovremennogo poryadka iz filosofii i politseyskoy praktiki [Police as Science and as Politics: On the Birth of the Contemporary Order from the Philosophy and Political Practice]" [in Russian]. Sotsiologicheskoye obozreniye [Russian Sociological Review] 12 (3): 9-40.

Koz'min, B.P. 1928. S. V. Zubatov i yego korrespondenty. Sredi okhrannikov, zhandarmov $i$ provokatorov [S. V. Zubatov and His Correspondents. Amongst the Guards, Gendarmes and Provocateurs] [in Russian]. Moskva [Moscow] and Leningrad: Gosudarstvennoye izdatel'stvo.

Kranikhel'd, V. 1917. "V. Ya. Yakovlev-Bogucharskiy (po materialam Departamenta politsii, Moskovskogo okhrannogo otdeleniya i po lichnym vospominaniyam) [V. Ya. Yakovlev-Bogucharsky (on the Materials of Police Department, Moscow Secret Police, and Personal Memories)]" [in Russian]. Byloye [The Past] 23 (1).

Martynov, A.P. 2004. "Moya sluzhba v Otdel'nom korpuse zhandarmov [My Service in The Special Gendarme Corps]" [in Russian]. In vol. 1 of Okhranka. Vospominaniya rukovoditeley politicheskogo syska [Okhrana. Memoirs of the Domestic Intelligence Head Officers]. 2 vols. Moskva [Moscow]: Novoye literaturnoye obozreniye.

Novitskiy, V.D. 1991. Iz vospominaniy zhandarma [From the Memories of a Gendarme] [in Russian]. Moskva [Moscow]: Izdatel'stvo MGU.

"O dvoryanine Ivane Petrove Belokonskom. L. 69-70. Doneseniye nachal'nika Orlovskogo zhandarmskogo upravleniya [Concerning Ivan Petrov Belokonskiy, a Nobleman. P. 69-70. Report of the Head of the Oryol Gendarmes Department]" [in Russian]. 1893. In GARF [State Archive of the Russian Federation]. 102/1893/820.

"O dvoryanine Mikhaile Ivanove Tugan-Baranovskom. L. 157. Spravka [About Nobleman Mikhail Ivanov Tugan-Baranovskiy. P. 157. Reference]" [in Russian]. 1899. In GARF [State Archive of the Russian Federation]. 102/3/1899/1055.

"O knyaze Dmitrii Ivanove Shakhovskom, obvinyayemom v politicheskoy neblagonadezhnosti. Perepiska [Concerning Prince Dmitriy Ivanov Shakhovskiy, Accused of Political Unreliability. Correspondence]" [in Russian]. 1903. In GARF [State Archive of the Russian Federation]. 102/7/1903/1791.

"O knyaze Dmitrii Ivanove Shakhovskom, obvinyayemom v politicheskoy neblagonadezhnosti. Perepiska [Concerning Prince Dmitry Ivanov Shakhovsky, Accused of Political Unrelia- 
bility. Correspondence]" [in Russian]. 1903. In GARF [State Archive of the Russian Federation]. 102/7/1903/1791/93.

"O knyaze Dmitrii Ivanoviche Shakhovskom. Perepiska [Concerning Prince Dmitry Ivanovich Shakhovsky. Correspondence]" [in Russian]. 1891. In GARF [State Archive of the Russian Federation]. 102/3/1891/527.

"O legal'noy oppozitsii. L. 3 ob.-4. Zapiska dlya pamyati [About Legal Opposition. P. 3 ob.-4. Note for Memory]" [in Russian]. 1902. In GARF [State Archive of the Russian Federation]. 102. Special Department. 1902/835.

"O legal'noy oppozitsii. L. 7. Zapiska dlya pamyati [About Legal Opposition. P. 7. Note for Memory]" [in Russian]. 1902. In GARF [State Archive of the Russian Federation]. 102 (Special Department). 1902/835.

"O moskovskom yuridicheskom obshchestve. L. 7, 11, 13-14, 15-16. Perepiska [Concerning Moscow Law Society. P. 7, 11, 13-14, 15-16. Correspondence]" [in Russian]. 1889. In GARF [State Archive of the Russian Federation]. 102/3/1889/87/503.

"O pomoshchnike prisyazhnogo poverennogo Petre Berngardove Struve. L. 162a. Zapiska [Concerning Petr Berngardovich Struve, an Assistant Attorney in Law. P. 162a. Note]" [in Russian]. 1894. In GARF [State Archive of the Russian Federation]. 102/3/91/1894/202.

"O professore Sankt-Peterburgskogo universiteta Petre Frantseve Lesgafte. L. 58. Tsirkulyar [Concerning Peter Frantsevich Lesgaft, a Professor of St. Petersburg University. P. 58. Circulaire]" [in Russian]. 1893. In GARF [State Archive of the Russian Federation]. $102 / 3 / 1893 / 91 / 434$.

"O sostoyashchikh pri Imperatorskom Vol'nom Ekonomicheskom obshchestve Sankt-Peterburgskom i Moskovskom komitetakh Gramotnosti. L. 120, 138-143. Perepiska [Concerning the St. Petersburg and Moscow Literacy Committees Attached to the Free Economic Society for the Encouragement of Agriculture and Husbandry. P. 120, 138-143. Correspondence]" [in Russian]. 1893. In GARF [State Archive of the Russian Federation]. $102 / 3 / 1893 / 91 / 635$.

"O soveshchaniyakh v dekabre 1901 g. i yanvare 1902 g. pod predsedatel'stvom gospodina direktora Departamenta politsii nachal'nikov nekotorykh gubernskikh zhandarmskikh upravleniy, v rayonakh koikh zamechayet-sya osoboye razvitiye revolyutsionnoy propagandy. L. 64 . Doneseniye nachal'nika Vladimirskogo zhandarmskogo upravleniya [Concerning Meetings in the December, 1901 and January, 1902 under the Chairmanship of Mr. Director of Department of Policy Chiefs of Some Provincial Gendarmes' Offices, in Areas where the Rise of Revolutionary Propaganda is Especially Noticed. P. 64. Report of the Head of the Vladimir Gendarmerie Department]" [in Russian]. 1901. In GARF [State Archive of the Russian Federation]. 102. Special Department. 1901/987.

"O syne nadvornogo sovetnika Genrikhe Adol'fove Fal'borke. L. 6. Spravka [Concerning Heinrich Adol'fovich Fal'bork, a Court Counselor's Son. P. 6. Reference]" [in Russian]. 1893. In GARF [State Archive of the Russian Federation]. 102/3/1893/1199.

"O tverskom zemstve. Vsepoddanneyshiy otchet. L. 3-16 [Concerning the Tver Zemstvo. The Most Allegiant Report. P. 3-16. Report]" [in Russian]. 1895. In GARF [State Archive of the Russian Federation]. 102/3/1895/1719.

"O vdove senatora taynogo sovetnika Aleksandre Mikhaylove Kalmykovoy. L. 6. Spravka [Concerning Aleksandra Mikhaylova Kalmykova, a Widow of the Senator of the Privy Councilor. P. 6. Reference]" [in Russian]. 1893. In GARF [State Archive of the Russian Federation]. 102/3/1893/1200.

"O zakrytii Moskovskogo Obshchestva vzaimopomoshchi lits intelligentnykh professiy. L. 2, 6. Doneseniye [Concerning Dismission of the Moscow Society Mutual-Aid for the Persons in 
the Intellectual Professions. P. 2, 6. Report]" [in Russian]. 1901. In GARF [State Archive of the Russian Federation]. 102/3/1901/933.

Pavlov, B. D. 1989. Esery-maksimalisty v Pervoy russkoy revolyutsii [Social-Revolutionary Maximalists in the First Russian Revolution] [in Russian]. Moskva [Moscow]: Izdatel'stvo Vsesoyuznogo zaochnogo politekhnicheskogo instituta.

Peregudova, Z. I. 2000. Politicheskiy sysk Rossii [Political Investigation in Russia] [in Russian]. Moskva [Moscow]: Rossiyskaya politicheskaya entsiklopediya.

"Po soobshcheniyam nachal'nika Tverskogo gubernskogo zhandarmskogo upravleniya. L. 87-89. Doneseniye [Reported by the Head of the Tver Provincial Gendarmerie Department. P. 87-89. Report]" [in Russian]. 1888. In GARF [State Archive of the Russian Federation]. 102/3/1888/84/23

"Po soobshcheniyam zaveduyushchego Parizhskoy agenturoy i po perepiske s nim. L. 280-281. Doneseniye [Reported by the Chief of Paris Net of Agents through Correspondence with Him. P. 280-281. Report]" [in Russian]. 1886. In GARF [State Archive of the Russian Federation]. 102/3/1888/89/32.

"Po soobshcheniyam zaveduyushchego Parizhskoy agenturoy i po perepiske s nim. L. 69-69 ob. Doneseniye [Reported by the Chief of Paris Net of Agents through Correspondence with Him. P. 69-69 ob. Report]" [in Russian]. 1891. In GARF [State Archive of the Russian Federation]. 102/3/1891/1.

"Politicheskiy obzor po Chernigovskoy gubernii. L. 15. Politicheskiy obzor [Political Review of Chernigov Governorate. P. 15. Political Review]" [in Russian]. 1905. In GARF [State Archive of the Russian Federation]. 102. Special Department. 1905/1/106/11.

"Politicheskiy obzor po Tverskoy gubernii. Politicheskiy obzor [Political Review of Tver Governorate. Political Review]" [in Russian]. 1885. In GARF [State Archive of the Russian Federation]. 102/3/1885/59/40/32.

"Politicheskiy obzor po Tverskoy gubernii. Politicheskiy obzor [Political Review of Tver Governorate. Political Review]" [in Russian]. 1885. In GARF [State Archive of the Russian Federation]. 102/3/1885/59/40/4.

"Politicheskiy obzor po Tverskoy gubernii. Politicheskiy obzor [Political Review of Tver Governorate. Political Review]" [in Russian]. 1888. In GARF [State Archive of the Russian Federation]. 102/3/1888/89/32/2.

"Politicheskiy obzor po Tverskoy gubernii. Politicheskiy obzor [Political Review of Tver Governorate. Political Review]" [in Russian]. 1889. In GARF [State Archive of the Russian Federation]. 102/3/1889/43/29.

"Politicheskiy obzor po Tverskoy gubernii. Politicheskiy obzor [Political Review of Tver Governorate. Political Review]" [in Russian]. 1885. In GARF [State Archive of the Russian Federation]. 102/3/81/1885/59/40/2.

"Proizvedeniya nelegal'noy pechati. Snosheniya chlenov Londonskoy gruppy s kruzhkom sankt-peterburgskikh liberalov, namerevayushchikhsya izdavat' v Londone svoy spetsial'nyy organ 'Zemskiy sobor'. L. 2 ob. Doneseniye zaveduyushchego Zagranichnoy agenturoy [Works of Illegal Press. between the Members of the London Group and the Group of St. Petersburg Liberals, Intending to Publish in London 'Zemsky Sobor', Their Special Organ of the Press. P. 2 ob. Reports of Chief of Paris Net of Agents]" [in Russian]. 1898. In GARF [State Archive of the Russian Federation]. 102 (Special Department). 1898/226/14/6.

Raeff, M. 1983. The Well-Ordered Police State: Social and Institutional Change through Law in the Germanies and Russia, 1600-1800. Yale University Press.

Revolyutsiya $i$ obshchestvennoye dvizheniye $v$ Sibiri v kontse XIX - nachale XX $v$. [Revolution and Social Movement in Siberia in the Late Nineteenth - Early Twentieth Century] [in Russian]. 1986. Novosibirsk: Nauka. 
Reyent, Yu. A. 2002. "Politseyskaya sistema Rossiyskoy imperii nachala XX v. (1900-1917) [Police System of the Russian Empire in the Beginning of Twentieth Century]" [in Russian]. Doctoral diss., Moskovskiy gosudarstvennyy universitet.

Ruud, Ch., and S. Stepanov. 1993. Fontanka, 16 [Fontanka, 16] [in Russian]. Moskva [Moscow]: Mysl'.

Samosudov, V. M. 1987. Bol'sheviki Sibiri v bor'be protiv tsarizma (1894-fevral' 1917 g.) [The Bolsheviks of Siberia in the Fight against Tsarism (1894-February 1917)] [in Russian]. Irkut.sk: Izdatel'stvo Irkut.skogo universiteta.

Shatsillo, K.F. 1985. Russkiy liberalizm nakanune revolyutsii [Russian Liberalism on the Eve of Revolution] [in Russian]. Moskva [Moscow]: Nauka.

Solov'yeva, M. V. 1966. "Tsarskiye provokatory i delo sotsial-demokraticheskoy fraktsii II Gosudarstvennoy Dumy [Tsarist Provocateurs and the Case of Social-Democratic Faction of the and State Duma]" [in Russian]. Voprosy istorii [Issues of History], no. 8.

Spiridovich, A. 1991. Zapiski zhandarma [Gendarme's Notes] [in Russian]. Moskva [Moscow]: Khudozhestvennaya literatura.

"Svod dannykh Departamenta Politsii o proyavleniyakh bor'by protiv pravitel'stva na legal'noy pochve v Sankt-Peterburge. L. 2. Zapiska dlya pamyati [The Set of Data of the Police Department on the Manifestations of the Fight against the Government on Legal Grounds in St. Petersburg. P. 2. Note for Memory]" [in Russian]. 1898. In GARF [State Archive of the Russian Federation]. 102. Special Department. 1898/723.

Svod zakonov Rossiyskoy imperii [The Code of Laws of the Russian Empire] [in Russian]. 1906. Vol. 1, bk. 2. Sankt-Peterburg [Saint Petersburg].

Uortman, R. [Wortman, R.] 2004. Vlastiteli i sudii: razvitiye pravovogo soznaniya $v i m$ peratorskoy Rossii [The Development of a Russian Legal Consciousness] [in Russian]. Trans. from the English by M. L. Dolbilov and F. L. Sevast'yanov. Moskva [Moscow]: Novoye literaturnoye obozreniye.

Vedernikov, V. V., V. A. Kitayev, and A. V. Lunochkin. 1997. Konstitutsionnyy vopros $v$ russkoy liberal'noy publitsistike 6o-8o-kh gg. XIX $v$. [The Issue of Constitution in the Russian Liberal Journalism of the 60-80-th Years of Nineteenth Century] [in Russian]. Moskva [Moscow]: Magistr.

"Vnutrennyaya agentura. Agenturnyye svedeniya iz Moskvy. L. 192-193. Perepiska [Internal Net of Agents. Intelligence Information from Moscow. P. 192-193. Correspondence]" [in Russian]. 1898. In GARF [State Archive of the Russian Federation]. 102. Special Department. $1898 / 2 / 1 / B$.

"Vnutrennyaya agentura. Lichnoye i denezhnoye delo sotrudnika M. I. Khar'kovtseva. L. 64. Zapiska [Internal Net of Agents. Personal Records and Expense Report of M. I. Garkavtsev, an Operative. P. 64. Note]" [in Russian]. 1898. In GARF [State Archive of the Russian Federation]. 102/316/1898/2/5/1.

Vtoroy s'yezd zemskikh deyateley [The Second Congress of Zemstvo Figures] [in Russian]. 1904. 6-9 noyabrya 1904 [6-9 November 1904], Sankt-Peterburg [Saint Petersburg].

"Zapiski nachal'nikov okhrannykh otdeleniy o revolyutsionnykh organizatsiyakh v ikh rayonakh. L. 48. Zapiska nachal'nika Moskovskogo otdeleniya po okhraneniyu obshchestvennoy bezopasnosti. O postanovleniyakh noyabr'skogo zemskogo s"yezda $1904 \mathrm{~g}$. [Notes by the Heads of Security Departments about the Revolutionary Organizations in Their Areas. P. 48. Notes by the Head of Moscow Department on the Protecting the Public Security and Order]" [in Russian]. 1904. In GARF [State Archive of the Russian Federation]. 102. Special Department. 1904/1195.

Ul'yanova (Bibikova), L. V. 2009a. “'Obezvredit' khirurgicheskimi merami nel'zya': liberal'noye dvizheniye glazami politicheskoy politsii (1880-1905 gg.) ['Cannot be Neutralised by 
a Surgical Intervention': Liberal Movement as Viewed by the Political Police (1880-1905)]" [in Russian]. In Trayektoriya $v$ segodnya: rossyp' istoriko-biograficheskikh artefaktov [Trajectory into Today: Scattering of the Historical and Biographical Artifacts], 232247. K yubileyu professora I. V. Narskogo [To the Anniversary of Professor I. V. Narsky]. Chelyabinsk: Entsiklopediya.

- . 2009b. "Politicheskaya politsiya i liberal'noye dvizheniye, 1880-1905 gg. [Political Police and Liberal Movement. 1880-1905]" [in Russian]. PhD diss., Moskovskiy gosudarstvennyy universitet.

- . 2009c. "Sotsial'no-professional'nyy portret politicheskoy politsii Rossiyskoy imperii (18801905) [Social and Professional Portrait of the Political Police in the Russian Empire (1880-1905)]" [in Russian]. Vestnik Permskogo universiteta [Perm University Herald] 9 (2): $92-101$.

Zavarzin, P. P. 2004a. "Zhandarmy i revolyutsionery [Gendarmes and Revolutionaries]" [in Russian]. In vol. 2 of Okhranka. Vospominaniya rukovoditeley politicheskogo syska [Okhrana. Memoirs of the Domestic Intelligence Head Officers]. 2 vols. Moskva [Moscow]: Novoye literaturnoye obozreniye.

- . 2004b. "Rabota taynoy politsii [The Work of the Secret Police]" [in Russian]. In vol. 1 of Okhranka. Vospominaniya rukovoditeley politicheskogo syska [Okhrana. Memoirs of the Domestic Intelligence Head Officers]. 2 vols. Moskva [Moscow]: Novoye literaturnoye obozreniye. 